\title{
Data collection methods for forest inventory: a comparison between an integrated conventional equipment and terrestrial laser scanning
}

\author{
Bogdan Apostol ${ }^{\S}$, Serban Chivulescu' ${ }^{1}$ Albert Ciceu' ${ }^{1}$, Marius Petrila ${ }^{1}$, Ionut-Silviu \\ Pascu $^{1,2}$, Ecaterina Nicoleta Apostol ${ }^{1}$, Ștefan Leca ${ }^{1}$, Adrian Lorenț ${ }^{1,2}$, Mihai Tănase ${ }^{1,3,4}$, \\ Ovidiu Badea ${ }^{1,2}$
}

Apostol B., Chivulescu Ș., Ciceu A., Petrila M., Pascu I.-S., Apostol E.N., Leca S., Lorenț A., Tănase M., Badea O., 2018. Data collection methods for forest inventory: a comparison between an integrated conventional equipment and terrestrial laser scanning. Ann. For. Res. 61(2): 189-202.

Abstract. This study aims to present a comparison analysis of two data collection methods that can be used in order to obtain reference ground truth data for forestry - a conventional method that uses specific equipment such as Field Map system, caliper and vertex inclinometer and a modern method based on terrestrial laser scanning (TLS) technology. The research was conducted in six circular Permanent Plots (PPs) with an area of 500 square meters each, within thinning and selected cuttings stands of sessile oak (Quercus petraea (Matt.) Liebl.), common beech (Fagus sylvatica L.) and Norway spruce (Picea abies L. Karst.), all situated in the Southern Carpathians (Mihăești, Muşeteși and Vidraru Forest Districts). Using the conventional method, the dendrometric tree characteristics such as height, diameter at breast height $(\mathrm{dbh})$ and tree position were directly recorded in the field. As a modern method for data collection, a Faro Focus3D X 130 HDR terrestrial laser scanning device was used to scan each plot and to extract the $\mathrm{dbh}$ and height of the trees. In this regard, two scanning approaches were used - single scan (SS) and multiple scan (MS). In order to compare the two data acquisitions methods, we applied a Strengths, Weaknesses, Opportunities, Threats (SWOT) analysis on the basis of which we could establish the pros and cons of using the two methods. Therefore, one can choose the most advantageous method for obtaining the reference data for forestry, in terms of equipment acquisition cost, personnel skills and qualifications, data collection working time, accuracy of the data recorded, post processing time, labor costs. Although the use of TLS in forest inventory is a technology with high potential, further investigations need to be done, especially in the case of automatic extraction of the tree height. For accurate reference ground data for forest inventory purposes, we still recommend using the conventional methods although they are time consuming.

Keywords: Field Map system, terrestrial laser scanning, forest inventory

Authors. "Marin Drăcea" National Research and Development Institute in Forestry, 128 B-dul. Eroilor, Voluntari, Ilfov, 077190 Romania | ${ }^{2}$ Faculty of 
Silviculture and Forest Engineering, "Transilvania" University of Braşov, 1 Sirul Beethoven, 500123, Romania ${ }^{3}$ Department of Geology, Geography, and Environment, University of Alcalá de Henares, Spain | ${ }^{4}$ School of Ecosystem and Forest Sciences, University of Melbourne, Australia.

$\S$ Corresponding author: Bogdan Apostol (bogdanap_ro@yahoo.com)

Manuscript received November 4, 2018; revised December 26, 2018; accepted December 29, 2018; online first December 31, 2018.

\section{Introduction}

The essential role of the forest ecosystems is to provide resources and ecological services, making them important for biodiversity conservation, soil protection and mitigation of climate change (Trumbore et al. 2015, Tubiello et al. 2015, Cabo et al. 2018).

The assessment of stand characteristics with high accuracy is a key aspect that has implications for the forest management activities, forest fire modeling and carbon stock estimation (Keenan et al. 2015, MacDicken 2015, Cabo et al. 2018). Methods for measuring the structural characteristics of the forest stands have rapidly evolved from the conventional to the modern ones. The conventional methods of measuring the structural characteristics of the forest have the ability to provide direct measurement, but the cost of producing them is rather high. In this regard, getting fast data at minimal cost became a necessity. Thereby one of the highest precision data acquisition devices that could be used in forestry is the terrestrial laser scanner (TLS) (Wang et al. 2017). Lately, the laser scanning technology was used for different activities such as mapping (Blair et al. 1999, Asner et al. 2014), photography (Niska et al. 2010, Wang et al. 2017) and surveying (Boehm et al. 2013).

Nowadays, TLS represents the most advanced method of determining field information (Zemánek et al. 2017). Compared with airborne and spaceborne laser scanning systems, the terrestrial laser scanning devices are used more locally in order to capture the details of the objects (Wang et al. 2017) and to collect the spatial information of the forest (Watt \& Donoghue 2005) as well as its struc190 tural characteristics (Maas et al. 2008, Lovell et al. 2011, Pueschel et al. 2013).

The aim of the study is to present a comparative analysis of two data collection methods that can be used in order to obtain reference ground data in forestry: a conventional method that use specific equipment - caliper and vertex inclinometer and a GIS recording with a field computer (Field Map system) and a modern method based on terrestrial laser scanning technology. The main objective was the analysis of the pros and cons of using the two methods, as a support to choose the most advantageous method to obtain reference data in forestry.

\section{Materials and methods}

The research was conducted in six circular Permanent Plots (PP) with an area of $500 \mathrm{~m}^{2}$ each, within thinning and selected cuttings stands of sessile Sessile oak (Quercus petraea (Matt.) Liebl.), common beech (Fagus sylvatica L.) and Norway spruce (Picea abies L. Karst.), all located in the Southern Carpathians (Mihăești, Mușătești and Vidraru Forest Districts) (figure 1). Each circular plot is part of a Permanent Sample Area (PSA) with a size of 1 ha that were installed in the framework of EO-ROFORMON project (http: //www.eo-roformon.ro).

As conventional method in our study we used the Field Map system (www.fieldmap. $\mathrm{cz}$ ), a combination of electronical caliper and vertex inclinometer to measure the trees characteristics (dbh, height and spatial position of trees) within each plot. Field Map system is a specialized equipment and software used 


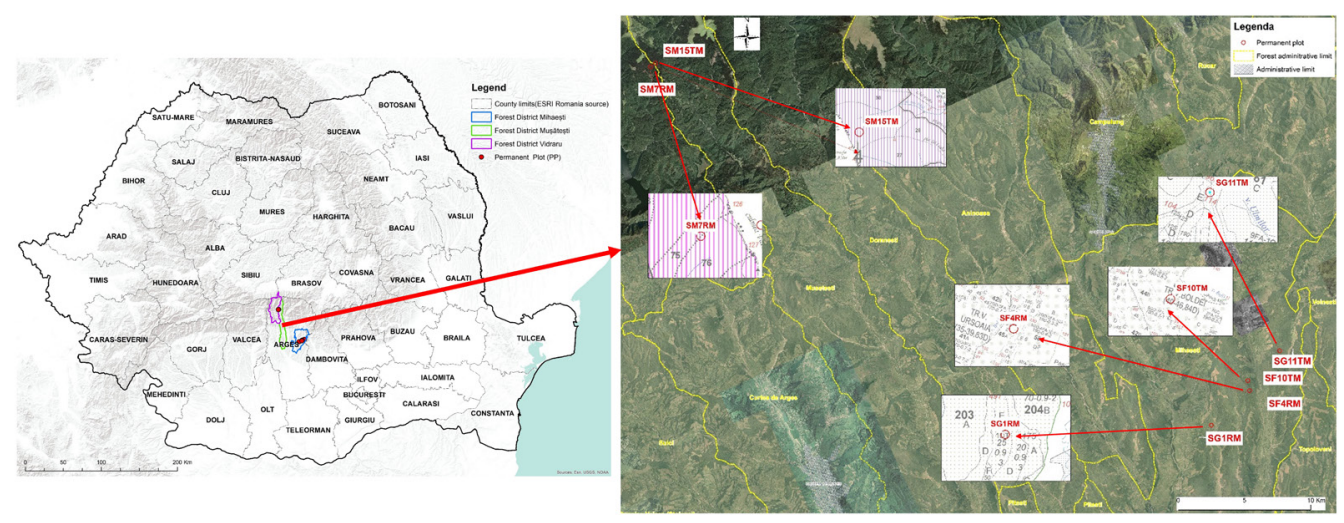

Figure 1 Study area

in forest inventories, which use a laser range finder, an inclinometer, an electronic compass mounted on a monopod and connected to a software (Field Map Data Collector) installed on a rugged tablet computer (Vopěnka \& Černý 2006). The software is used to structure the database characteristics, to record the field measurements and for the geospatial processing. In order to get reference ground data this technology was used in remote sensing studies based both on passive (Bernasconi et al. 2017, Brovkina et al. 2018) and active sensors (Brovkina et al. 2017, Tockner et al. 2017).

In each plot and by the use of the Field Map system, we directly assessed the tree position and the species. For a better productivity, dendrometric tree characteristics ( $\mathrm{dbh}$, tree height) were measured using a caliper and a Vertex IV inclinometer and the data were imported in Field Map Data Collector software. For further geospatial analysis, the central coordinates of each plot were recorded with a Trimble GeoXH 6000 GNSS receiver equipped with a Zephyr external antenna. The GNSS data were differential post processed using EUREF (European reference frame) stations and used to convert the Field Map measured data from local to global coordinates.

The use of the terrestrial laser scanning technology to extract the dendrometric characteristics of the trees is considered to be a modern method, which could have favorable implica- tions in forestry practice. We used a Faro Focus3D X 130 HDR Terrestrial Laser Scanning device to scan the trees within each plot (figure 2). This version of the TLS is a phase-shift based scanner, the distance between the scanner and the target being calculated accordingly with the shift in phase of the returned modulations (Newnham et al. 2011).

In our study, two scanning approaches were used - a single scan (SS) and multiple scan (MS) (figure 3). In multiple scan approach, the TLS stations were placed in the plot center and according the cardinal directions (north, east, south, and west) at a distance of $15 \mathrm{~m}$ from the center of the plot. The most important parameters that can be set up before the scanning operation are the resolution and the quality. Based on literature (Stanley 2013), the chosen values of theese, considered for the forested areas were: $1 / 4$ for resolution and $3 x$ for the quality. Thereby, all the trees near the border of the circular plot were recorded. For co-registration purpose, in each plot there were placed 7 white spheres with a $14 \mathrm{~cm}$ diameter, so that from each TLS station should be seen at least four of them. The co-registration of the TLS point clouds was made with the Faro Scene software (http://www.faro.com). Further, the point clouds were post processed with Computree software (http://www.computree. onf.fr), to extract the ground level (the digital terrain model - DTM) of each plot (Othmani et 


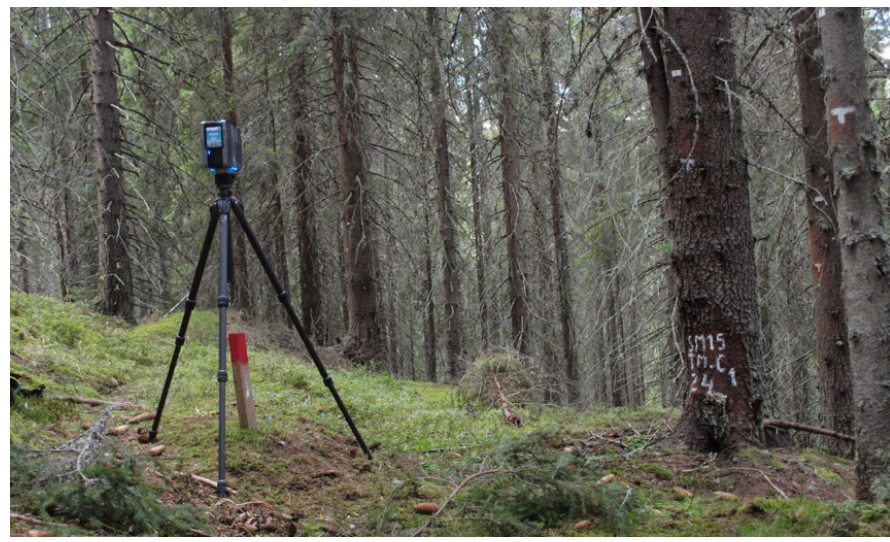

Figure 2 Faro Focus3D X 130 HDR Terrestrial Laser Scanning (TLS) - in scan position (plot SM15TM)

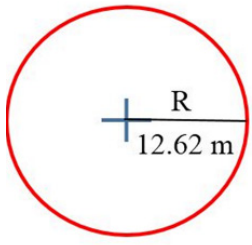

a)
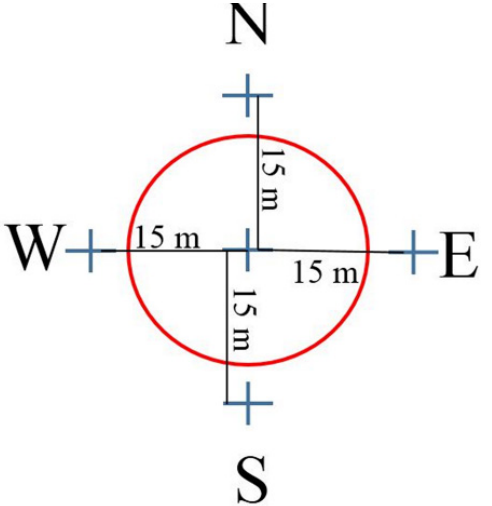

b)

Figure 3 TLS scanning approaches: a) single scan (SS) b) multiple scan (MS)

al. 2011), and the dbh and height of its trees. A randomized Hough transformation (Simonse et al. 2003, Aschoff \& Spiecker 2004) was applied as an automatic method that allows detection of tree trunks as clusters of points. The tree dbh was estimated by fitting a geometric circle into a trunk slice located at 1.25-1.35 above the ground level. The tree height was calculated as the difference between the lowest point (ground level) and the highest point inside of one cluster.

The TLS estimated dbh, height and positions of the trees within each plot were clipped according to the $500 \mathrm{~m}^{2}$ plot border. The result-

ed data were then compared with the Field Map inventory data at the plot level, without making the individual tree identification between the datasets. To eliminate the observations which may induce errors to the final results - e.g. outliers or measurement errors - we used different methods to clean the data. On the Field Map inventory data obtained with the caliper (dbh) and Vertex IV (heights), a statistic approach where all values below the first quantile and above third quantile would be considered outliers could not be applied. This is was choosed because the analyzed stands have higher coefficients of variation of dbh and an associated inverse-J shaped distribution, characteristic to uneven-aged stands or where the selected cuttings are applied. In order to eliminate the outliers in an objective way, we used the ratio between height $(\mathrm{m})$ and $\mathrm{dbh}(\mathrm{cm})$. This index is a good indicator of trees mechanic stability; we accepted an interval of 0.6 and 1.7 for eliminating trees with unreal height or dbh as such values of the index were studied before (Grudnicki 2004) for different production classes and species. We also eliminated all the trees having a top break, being dead or having merged stems. For the trees obtained by the TLS method, we eliminated all values above the maximum and below the minimum height and the dbh values which had been assessed in the Field Map inventory.

To compare the two acquisitions methods and its output data, we also applied a Strengths, Weaknesses, Opportunities, Threats (SWOT) 
analysis. Several aspects where considered in this analysis: the equipment acquisition cost, the personnel skills and qualifications, the data collection working time, the type of the data recorded, the post processing time, the accuracy of the data recorded and the labor costs.

\section{Results}

\section{Equipment acquisition costs and personnel skills}

Regarding the cost, we can say that the conventional method uses much cheaper equipment than the modern method. Lately, the price of a Faro Focus ${ }^{3 \mathrm{D}}$ X130HDR that includes a dedicated post processing software (Faro Scene software) is about 48,000 Euros, which is 2.8 times more than the total price of the Field Map system, with caliper and vertex inclinometer. With the technological advance, we are convinced that terrestrial lasers will become more affordable in terms of price and thus would be used as much as possible in forested areas.

In terms of personnel skills and qualifications, the method based on TLS technology has the advantage of a less numerous field team, but the processing of TLS raw data requires a highly skilled staff (Table 1).

\section{Data collection, working time}

The results on the necessary working time for recording the field data indicated that the use of TLS was faster than the classic method (Table 2, Table 3 ). The effective scanning time for a single scan was 7 minutes and 47 seconds. Positioning the spheres in the plot for further

Table 1 Comparison of measurement and processing activities

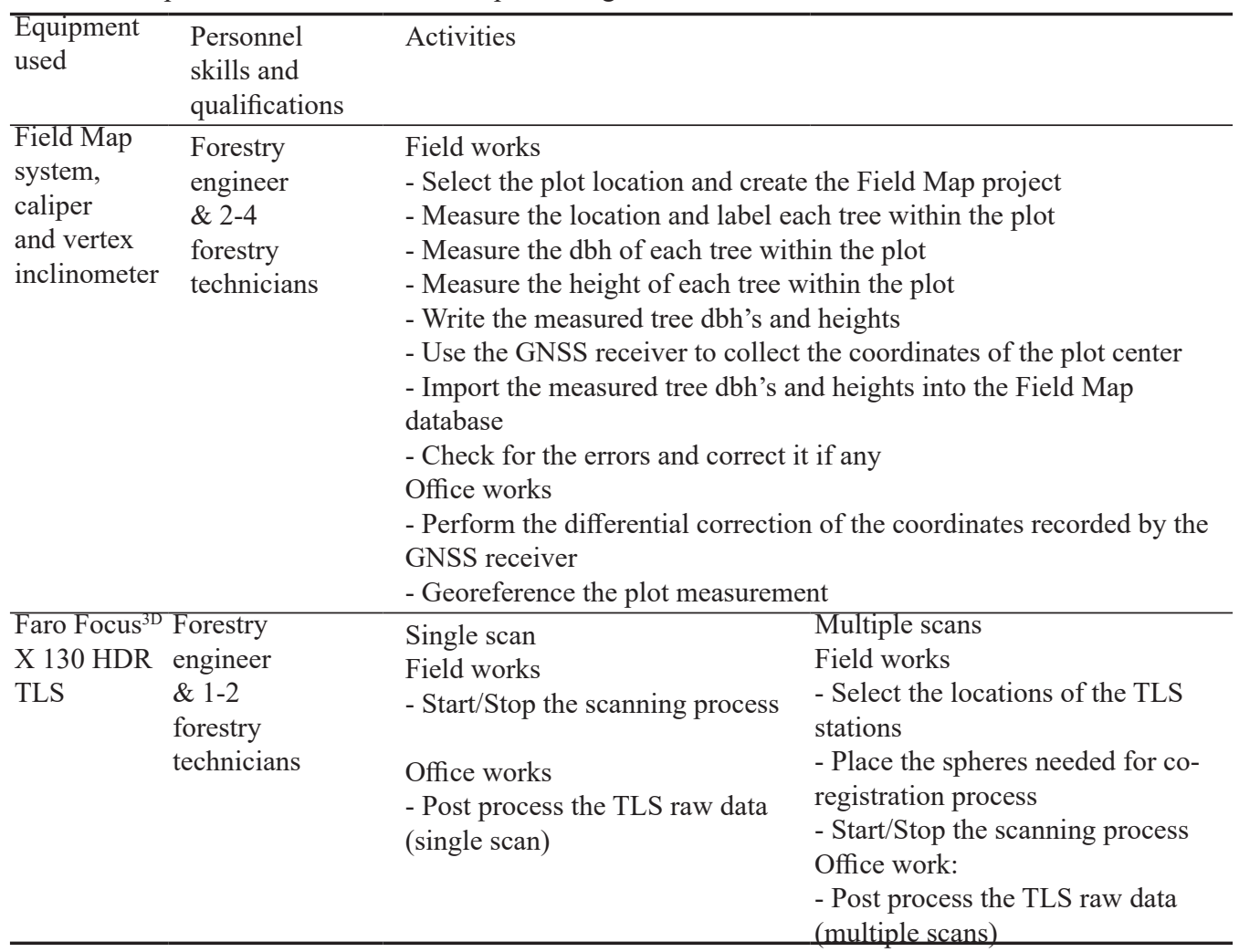


Table 2 Working time for Field Map system, caliper and vertex inclinometer

\begin{tabular}{|c|c|c|c|c|c|c|c|}
\hline Stand & Number & Estimated time fo & or the activity ( $h$ & ours) & & & Total \\
\hline $\begin{array}{l}\text { compo- } \\
\text { sition, } \\
\text { forestry } \\
\text { works } \\
\text { (plot code) }\end{array}$ & $\begin{array}{l}\text { of trees } \\
\text { within } \\
\text { the plot }\end{array}$ & $\begin{array}{l}\text { Create the Field } \\
\text { Map project } \\
\text { and measure the } \\
\text { location of each } \\
\text { tree }(\mathrm{dbh}>6 \mathrm{~cm}) \\
\text { within the plot }\end{array}$ & $\begin{array}{l}\text { Measure } \\
\text { the crown } \\
\text { projection of } \\
\text { each tree (dbh } \\
>6 \mathrm{~cm} \text { ) within } \\
\text { the plot }\end{array}$ & $\begin{array}{l}\text { Measure the } \\
\mathrm{dbh}(>6 \mathrm{~cm}) \\
\text { of each tree } \\
\text { within the } \\
\text { plot }\end{array}$ & $\begin{array}{l}\text { Measure } \\
\text { the height } \\
\text { of each tree } \\
\text { within the } \\
\text { plot }\end{array}$ & $\begin{array}{l}\text { Completing } \\
\text { and importing } \\
\text { dbh-height } \\
\text { data }\end{array}$ & $\begin{array}{l}\text { time } \\
\text { (hours) }\end{array}$ \\
\hline $\begin{array}{l}\text { Sessile oak, } \\
\text { thinning } \\
\text { (SG1RM) }\end{array}$ & 135 & 4 & - & 2 & 4 & 1 & 11 \\
\hline $\begin{array}{l}\text { Sessile oak, } \\
\text { selected } \\
\text { cuttings } \\
\text { (SG11TM) }\end{array}$ & 35 & 1 & 1 & 0.5 & 1 & 0.5 & 4 \\
\hline $\begin{array}{l}\text { Common } \\
\text { beech, } \\
\text { thinning } \\
\text { (SF4RM) }\end{array}$ & 64 & 2 & - & 1 & 3 & 1 & 7 \\
\hline $\begin{array}{l}\text { Common } \\
\text { beech, } \\
\text { selected } \\
\text { cuttings } \\
\text { (SF10TM) } \\
\end{array}$ & 31 & 1 & 1 & 0.5 & 1 & 0.5 & 4 \\
\hline $\begin{array}{l}\text { Norway } \\
\text { spruce, } \\
\text { thinning } \\
\text { (SM7RM) }\end{array}$ & 92 & 3 & - & 2 & 3 & 1 & 9 \\
\hline $\begin{array}{l}\text { Spruce, } \\
\text { selected } \\
\text { cuttings } \\
\text { (SM15TM) }\end{array}$ & 32 & 1 & 1 & 0.5 & 1 & 0.5 & 4 \\
\hline
\end{tabular}

co-registration of the scans during the multiple scan approach could be a time-consuming activity. By contrast, using the traditional method in the young stands, where the number of trees is quite high, the working time can reach 11 hours (Sessile oak stand with forest thinning).

\section{Types of data recorded}

The Field Map Data Collector directly measured in the field the tree positions and their crown projections and further recorded in a local coordinate system (figure 4a). The caliper 194 was used to measure the tree $\mathrm{dbh}$ and the Vertex inclinometer for tree heights; afterwards all the measurements were transferred to the Field Map Data Collector. One important issue concerning the Field Map use: it provides directly in the field the correlation between $\mathrm{dbh}$ and trees heights (figure 4b) and thus offer the possibility to remeasure the trees for which errors seemed likely. In the case of terrestrial laser scanning, are recorded point clouds and images in natural colors (RGB) (figure 5), and those point clouds need to be post-processed at office. 
Table 3 Working time for Faro Focus3D X 130 HDR TLS

\begin{tabular}{lll}
\hline Stand composition, forestry work (plot code) & $\begin{array}{l}\text { Single scan } \\
\text { (minutes) }\end{array}$ & $\begin{array}{l}\text { Multiple scans } \\
\text { (minutes) }\end{array}$ \\
\hline Sessile oak, thinning (SG1RM) & 15 & $60-90$ \\
\hline Sessile oak, selected cuttings (SG11TM) & 15 & 60 \\
\hline Common beech, thinning (SF4RM) & 15 & $60-90$ \\
\hline Common beech, selected cuttings (SF10TM) & 15 & 60 \\
\hline Norway spruce, thinning (SM7RM) & 15 & $60-90$ \\
\hline Norway spruce, selected cuttings (SM15TM) & 15 & 60 \\
\hline
\end{tabular}

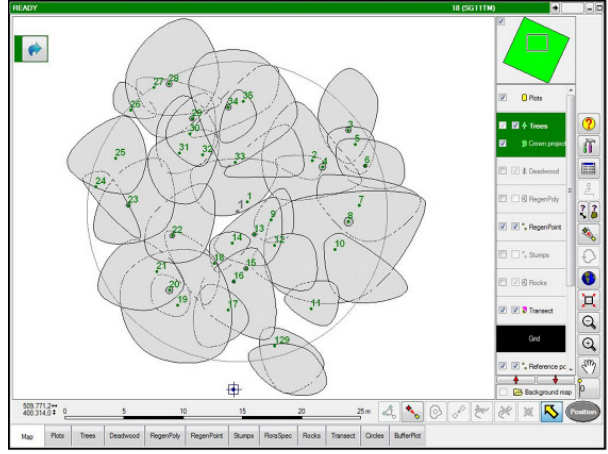

a)

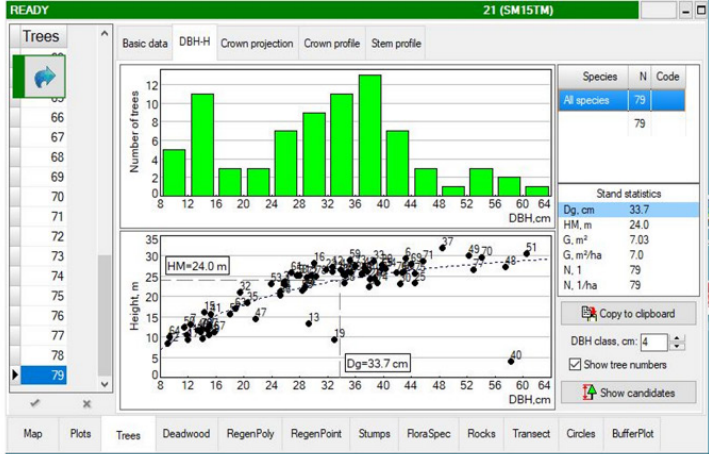

b)

Figure4 Field Map system a) tree crown projections b) correlation between trees $\mathrm{dbh}$ - height
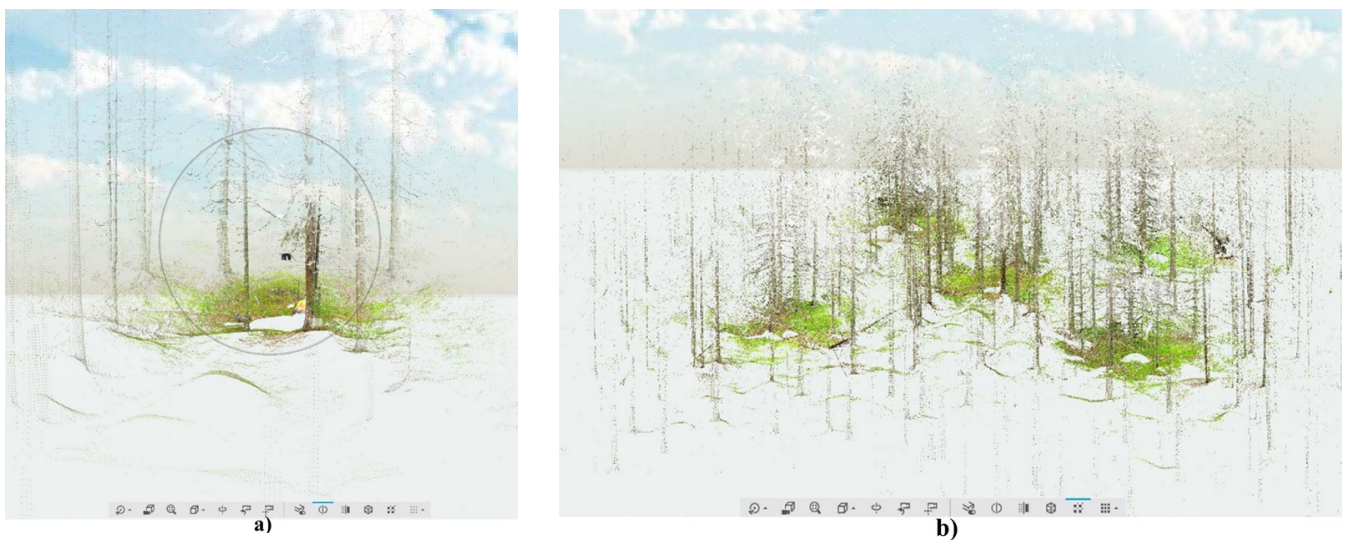

Figure 5 TLS recorded data: a) Single scan point cloud (Faro Scene software) (SS) b) Multiple scans point cloud (Faro Scene software) 


\section{Post-processing time}

The conventional method presents the advantage that the resulted data are in GIS already, measured in local coordinates - simple and easy to use immediately, with minimum or no further office processing method. By contrast, TLS data need to be post-processed in order to get values for the tree dbh and height. The post processing time could be up to 10 hours in the case of young stands, with a higher density of trees (Sessile oak forest stand - thinning) (Table 4).

\section{Accuracy of the data recorded}

By comparing averages of the dbh for each plot measured both by conventional and TLS methods, in the case of single scan approach we obtained deviations in absolute values, ranging from $0.4 \mathrm{~cm}$ (common beech thinning stand - SF4RM) to $6.4 \mathrm{~cm}$ (common beech selected cuttings stand - SF10TM). When using a multiple scan approach, the deviations were higher, ranging between $0 \mathrm{~cm}$ (spruce selected cuttings stand - SM15TM) and $13.7 \mathrm{~cm}$ (SF10TM) (Table 5, figure 6).

Within the stands with high dbh coefficients of variation, the differences between the averages, both dbh and height, of the two popula- tions are high, suggesting a lower accuracy for the TLS trees detection, and for their dbh and height, than in stands with a low variability of $\mathrm{dbh}$. In the case of a coefficient of variation of dbh less than $35-40 \%$, the difference between the average dbh obtained by the two methods (conventional and modern) is relatively low (less than $2 \mathrm{~cm}$ in both approaches, single and multiple scans).

The tree height was underestimated when used both the TLS methods (single and multiple approach), with a lower value in the case of the multiple approach. The deviation between the average height of each plot, measured both by conventional and TLS methods, were higher than in the case of dbh, ranging between 4.8 $\mathrm{m}$ (sessile oak thinning stand - SG1RM) and $18.5 \mathrm{~m}$ (SF4RM), for single scan approach, respectively between $3.2 \mathrm{~m}$ (SG1RM) and $11.4 \mathrm{~m}$ (sessile oak selected cuttings stand - SG11TM) in the case of the multiple scan approach (Table 5, Figure 7). The underestimations of the height by the TLS measurement could be related to the treetops, which are sometimes not visible due to occlusions of the other tree crown or because their position, nearby the scanner station.

Table 4 Post processing time for Faro Focus3D X 130 HDR TLS system

\begin{tabular}{llllll}
\hline \multirow{2}{*}{$\begin{array}{l}\text { Code of the } \\
\text { permanent } \\
\text { plot }\end{array}$} & $\begin{array}{l}\text { Estimated time for the activity (hours) } \\
\text { TLS scans } \\
\text { co-registration } \\
\text { (Faro Scene }\end{array}$ & $\begin{array}{l}\text { Extracting the } \\
\text { Digital Terrain } \\
\text { Model (DTM) } \\
\text { (Computree }\end{array}$ & $\begin{array}{l}\text { Point cloud } \\
\text { segmentation } \\
\text { (Computree }\end{array}$ & $\begin{array}{l}\text { Extract trees charac- } \\
\text { teristics (dbh, height, } \\
\text { positions) (Computree } \\
\text { software) }\end{array}$ & $\begin{array}{l}\text { Total } \\
\text { (hours) }\end{array}$ \\
\hline SG1RM & 2 & 1 & $4-5$ & 2 & 10 \\
SG11TM & $1.5-2$ & 1 & 3 & 2 & 8 \\
SF4RM & 2.5 & 1 & $4-5$ & 2 & 10 \\
SF10TM & $1.5-2$ & $1-1.5$ & 3 & 2 & 8 \\
SM7RM & $2.5-3$ & 1 & 4 & $1.5-2$ & 10 \\
SM15TM & 2 & 1 & $3-3.5$ & 1.5 & 8 \\
\hline s.tware)
\end{tabular}

Note. Abbreviations: * The code of permanent plot is according to Table 2. 
Table 5 Accuracy of the recorded data

\begin{tabular}{|c|c|c|c|c|c|c|c|c|c|c|c|}
\hline \multirow[b]{2}{*}{$\begin{array}{l}\text { Code of } \\
\text { permanent } \\
\text { plot* }\end{array}$} & \multicolumn{3}{|c|}{$\begin{array}{l}\text { Field Map system, caliper } \\
\text { and vertex inclinometer }\end{array}$} & \multicolumn{4}{|c|}{$\begin{array}{l}\text { Faro Focus }^{3 \mathrm{D}} \text { X } 130 \mathrm{HDR} \\
\text { TLS - SS }\end{array}$} & \multicolumn{4}{|c|}{$\begin{array}{l}\text { Faro Focus }{ }^{3 \mathrm{D}} \text { X } 130 \mathrm{HDR} \\
\text { TLS - MS }\end{array}$} \\
\hline & $\begin{array}{l}\overline{d b h} \\
(\mathrm{~cm})\end{array}$ & $\begin{array}{l}\text { Coeficient } \\
\text { of variation } \\
\text { of the dbh } \\
\text { measured in } \\
\text { the field } \\
(\%)\end{array}$ & $\begin{array}{c}\bar{h} \\
(\mathrm{~m})\end{array}$ & $\begin{array}{l}\overline{d b h} \\
(\mathrm{~cm})\end{array}$ & $\begin{array}{c}\bar{h} \\
(\mathrm{~m})\end{array}$ & $\begin{array}{l}\Delta \mathrm{dbh} \\
(\mathrm{cm})\end{array}$ & $\begin{array}{l}\Delta \mathrm{h} \\
(\mathrm{m})\end{array}$ & $\begin{array}{l}\overline{d b h} \\
(\mathrm{~cm})\end{array}$ & $\begin{array}{c}\bar{h} \\
(\mathrm{~m})\end{array}$ & $\begin{array}{l}\Delta \mathrm{dbh} \\
(\mathrm{cm})\end{array}$ & $\begin{array}{l}\Delta \mathrm{h} \\
(\mathrm{m})\end{array}$ \\
\hline SG1RM & 12.5 & $28 \%$ & 15.7 & 11.0 & 11.0 & 1.5 & 4.8 & 11.2 & 12.5 & 1.3 & 3.2 \\
\hline SG11TM & 30.0 & $78 \%$ & 25.5 & 26.3 & 9.5 & 3.7 & 16.1 & 23.4 & 14.1 & 6.6 & 11.4 \\
\hline SF4RM & 19.8 & $37 \%$ & 26.5 & 20.2 & 8.0 & -0.4 & 18.5 & 18.0 & 15.5 & 1.8 & 10.9 \\
\hline SF10TM & 21.0 & $96 \%$ & 19.0 & 27.4 & 11.4 & -6.4 & 7.6 & 34.7 & 13.1 & -13.7 & 5.9 \\
\hline SM7RM & 16.1 & $47 \%$ & 15.0 & 18.6 & 8.6 & -2.5 & 6.4 & 18.3 & 9.7 & -2.2 & 5.3 \\
\hline SM15TM & 30.6 & $31 \%$ & 22.8 & 29.2 & 10.6 & 1.4 & 12.2 & 30.6 & 14.8 & 0.0 & 8.0 \\
\hline
\end{tabular}

Note. Abbreviations: ${ }^{*}$ The code of permanent plot is according to Table 2 .

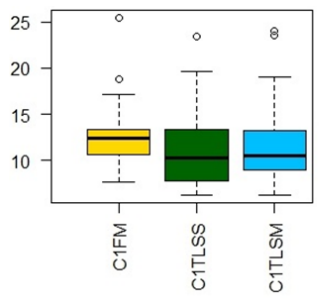

a)

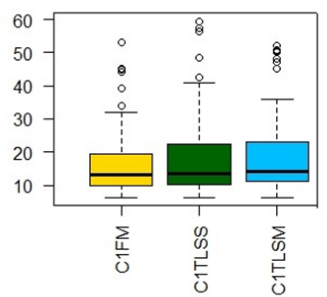

f)

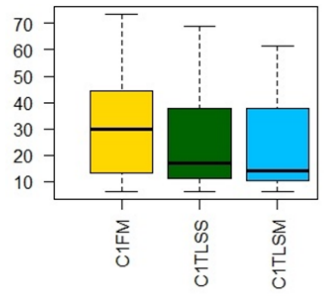

b)

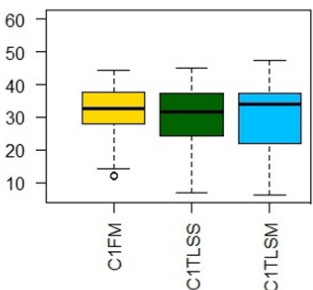

e)

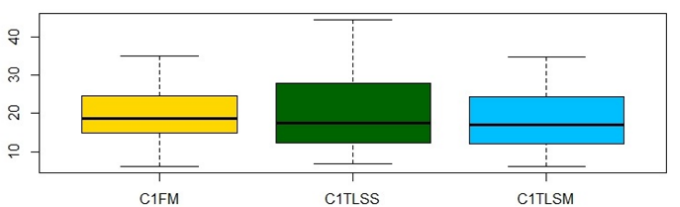

c)

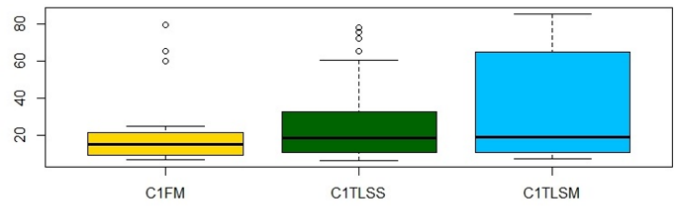

d)

Figure 6 Boxplot of dbh measured in the field (FM) and the TLS estimated - TLSS (single scan), TLSM (multiple scan) a) SG1RM, b)SG11TM, c) SF4RM, d) SF10TM, e) SM15TM f) SM7RM

\section{Labor costs}

Labor cost for one of the measured plot was slightly higher when we used the conventional method (approximatively 1.7 times higher than TLS method). Considering all of the above-mentioned aspects, the SWOT analysis is presented in Table 6 .

\section{Discussion}

The study intended to compare two acquisitions methods, to obtain reference ground truth data for forestry and to analyze its suitability by applying a SWOT analysis.

Modern technology, such as TLS, is reducing the fieldwork time, but the data provided 


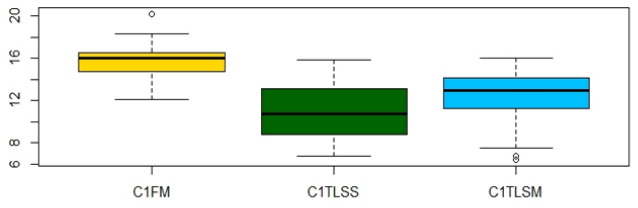

a)

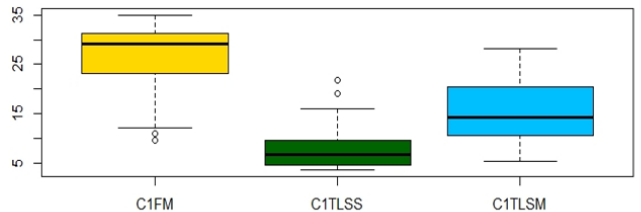

c)

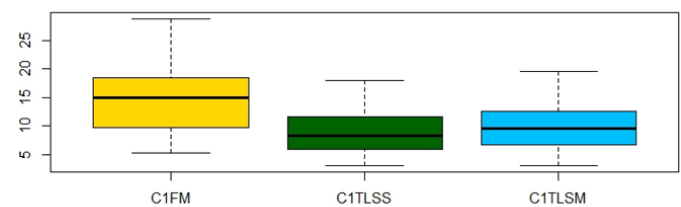

e)

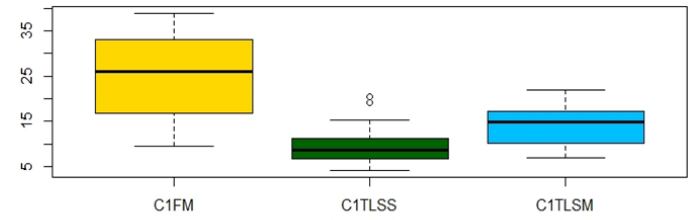

b)

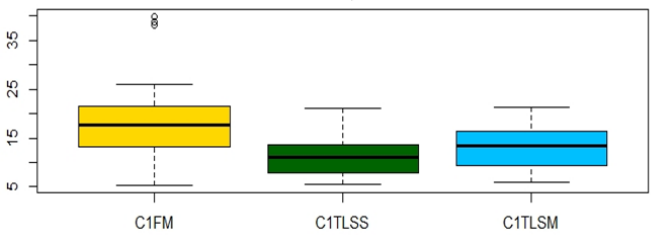

d)

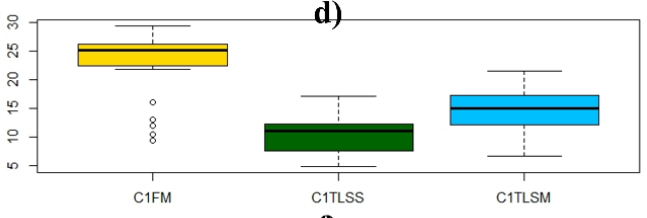

f)

Figure 7 Boxplot of height measured in the field (FM) and the TLS estimated - TLSS (single scan), TLSM (multiple scan) a) SG1RM, b) SG11TM, c) SF4RM, d) SF10TM, e) SM7RM, f) SM15TM

should be processed in order be usable and useful. Referring to the importance of using TLS technology in forestry, Wang et al. 2017 considered the new technology very useful in forest inventory, but the high price of the devices is still a drawback.

In this study, the working time required in a multiple scan approach, considering both activities - placing the spheres in the field and scanning - was approximately 60-90 minutes per plot. Bauwens et al. (2016) indicated, for a multiple scan approach and only for positing the spheres within the plot, a required time of 40 minutes. They used in their study the Faro Focus3D 120 device, which is similar to the TLS used by us. In the present study, the estimated working time necessary in the use of conventional method ranged between 4 hours (sessile oak, common beech and Norway spruce selected cuttings stands) and 11 hours (sessile oak, common beech and Norway spruce thinning stands). On the working time and the TLS practical application, Wezyk et al. 198
(2007) pointed that the TLS methods are suitable for small areas, in monitoring and modelling the growth of the trees and stands, while for large sampling areas are not very successful, due to the time consuming for automatic data processing.

A study of Weiß (2009) indicates that the multiple scan approach is superior to single scan one, revealing better results in terms of dbh estimation and trees recognition; still, fully automatic tools are further needed for these approaches to be used for practical forest inventory purposes.

Using the single scan (SS) approach, we obtained, at plot level, a deviation between the mean dbh of the Field Map measurements and the mean dbh estimated by automatic TLS method ranging from $-6.4 \mathrm{~cm}$ (SG10TM) to $3.7 \mathrm{~cm}$ (SG11TM), with an average of -0.5 for all the six measured plots. The results for dbh using the multiple scan (MS) approach were in the interval $-13.7 \mathrm{~cm}$ (SF10TM) and $6.6 \mathrm{~cm}$ (SG11TM), with an average of $-1.0 \mathrm{~cm}$. Within 
Table 6 SWOT analysis

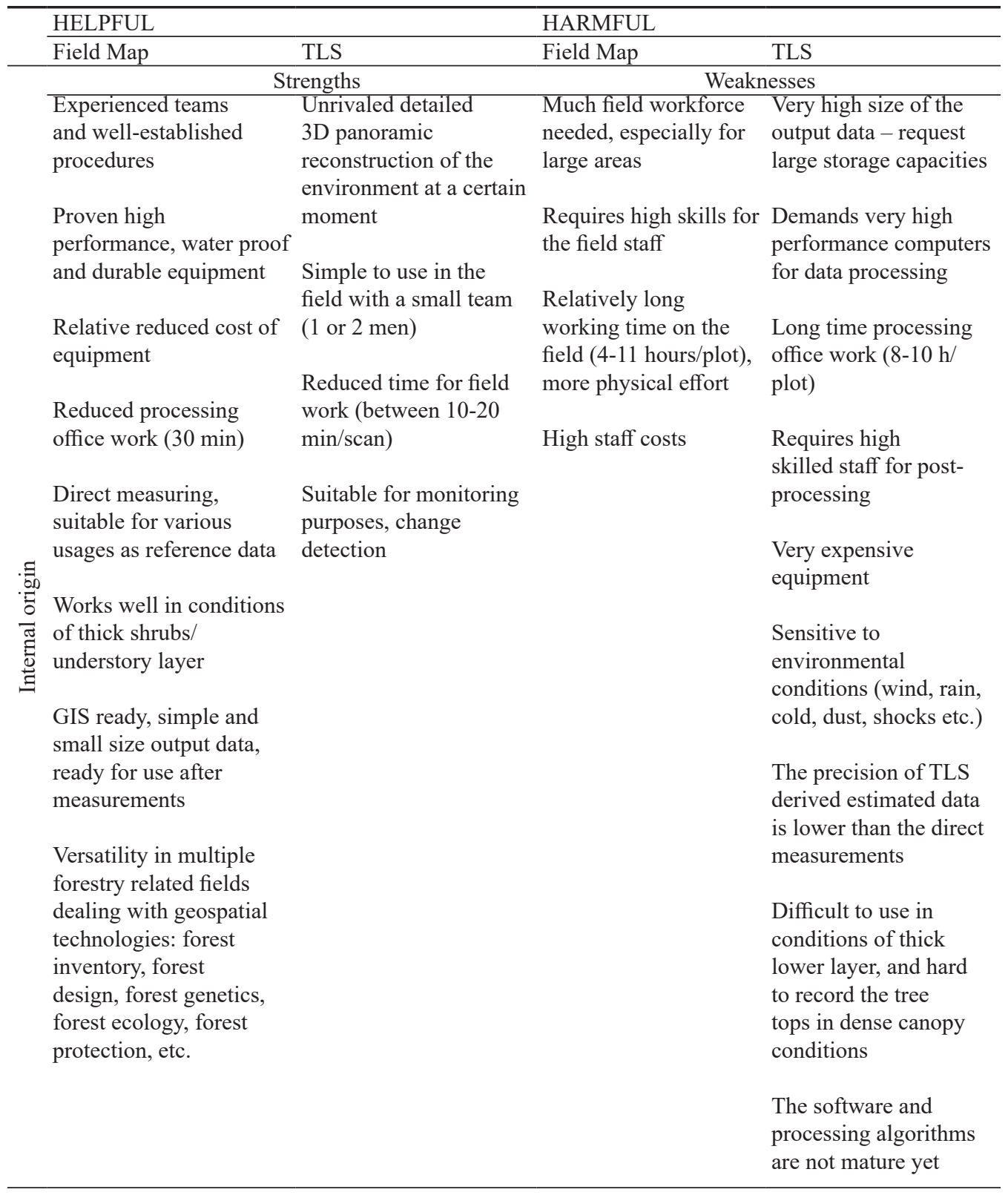

the stands with a low coefficient of variation of dbh (less than 35-40\%), the difference between the average dbh obtained with the two methods (conventional and modern) is relatively low, being less than $2 \mathrm{~cm}$. Using a phase-shift TLS device (Faro LS 800 HE80) and SS in 3 plots
( 2 plots with mixed forest tree species and 1 pure beech forest plot) with a radius of $15 \mathrm{~m}$, Maas et al. (2008) obtained a bias between -0.7 and $1.6 \mathrm{~cm}$ of $\mathrm{dbh}$. In the beech forest plot, the dbh bias was underestimated with $1.6 \mathrm{~cm}$, while in our study we obtained only an overes- 
Table 6 (continuation)

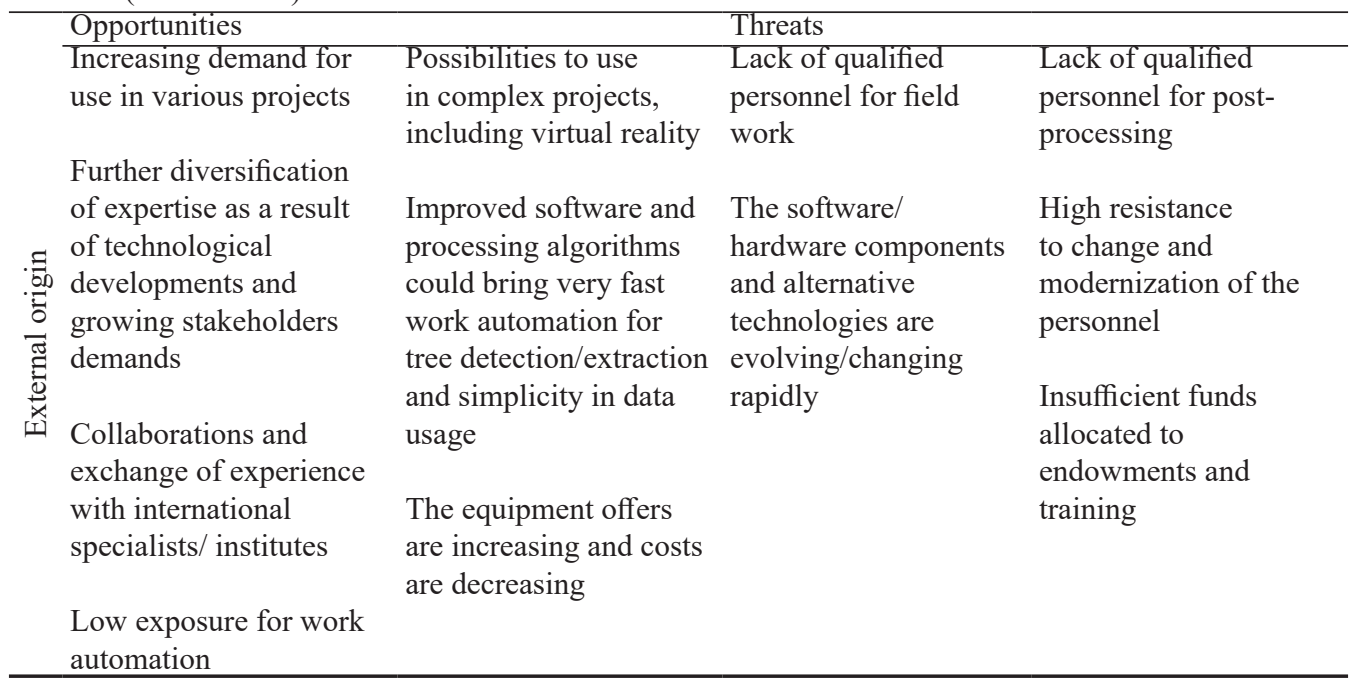

timation of $0.4 \mathrm{~cm}$. Using a Riegl LMS-Z420i TLS device and MS method they obtained for another beech forest plot a dbh bias of $0.9 \mathrm{~cm}$, better with $0.9 \mathrm{~cm}$ than the one obtained in our study.

Brolly \& Kiraly (2009) applied SS in a mixed forest (sessile oak, hornbeam, beech, larch and spruce species), in one plot with a radius of $30 \mathrm{~m}$. The estimation bias for $\mathrm{dbh}$ was from -1.6 to $0.5 \mathrm{~cm}$ (i.e. the dbh was measured by 3 methods). In other study, Liang \& Hyyppä (2013) scanned 5 plots of $10 \mathrm{~m}$ radius in a boreal forest with Scots pine, Norway spruce and birch with densities between 605 and 1,210 stems $\mathrm{ha}^{-1}$; the reference measurements included trees with at least $5 \mathrm{~cm}$ dbh and they reported biases from -0.2 to $0.8 \mathrm{~cm}$ for the $\mathrm{SS}$ approach, while using a specific MS method the dbh bias was ranging from 0.1 to $0.7 \mathrm{~cm}$. In their work, for SS approach applied in the dominant Norway spruce stand (plot 5) the dbh bias obtained was better with $0.8 \mathrm{~cm}$ than the one obtained in our study (SM15TM plot). In the case of MS method, while the dbh bias obtained in their study was $0.6 \mathrm{~cm}$, we obtained no difference between the mean values of the dbh.

In a previous estimations of the tree height 200 based on the TLS, Liang et al. (2016) indicated the difficulty of identifying treetops in dense forested plots. With the SS approach, we obtained, at plot level, a high deviation between the mean height based on Field Map measurements and the mean height estimated by automatic TLS method ranging from $4.8 \mathrm{~m}$ (SG1RM) to $18.5 \mathrm{~m}$ (SF4RM) with an average of $10.9 \mathrm{~m}$ for all the six measured plots. Likewise, following the MS approach, the biases were between $3.2 \mathrm{~m}$ (SG1RM) and $11.4 \mathrm{~m}$ (SG11TM), with an average of $-1.0 \mathrm{~m}$. The very high deviations obtained with the both approaches indicate that TLS underestimate the tree height. Still, there are necessary more investigations to get accurate tree height data using this technology. Reliable height measurements based on TLS seems to be possible in sparse forested plots (Fleck et al. 2011, Huang et al. 2011). Liang \& Hyyppä (2013) obtained a height bias between -1.3 and $2.15 \mathrm{~m}$ with the SS approach, and between -0.34 and $2.11 \mathrm{~m}$ using the MS method. Olofsson et al. (2014) reported the use of the SS method on 16 plots, with a resulted bias of $-0.1 \mathrm{~m}$, while in another study (Huang et al. 2011) the bias value was of $-0.3 \mathrm{~m}$ for heights estimates (a single plot with a density of 212 stems/ha). 


\section{Conclusions}

The difference between the average dbh obtained by the two methods (conventional and modern) is relatively low, being less than $2 \mathrm{~cm}$ in stands with a low coefficient of variation of dbh.

In the case of tree heights, the comparison between the two methods revealed a considerable underestimation in both the TLS methods (the single and the multiple approach), with a less value for the later.

Although it is a technology with a higher potential, for a large use of TLS in forest inventory further investigations are required, especially in the case of automatically extraction of the tree height. To obtain accurate reference ground data for forest inventory purposes, we still recommend the use of the conventional methods, although they are time consuming.

\section{Acknowledgements}

This research was made possible through the funding provided by the Romanian Ministry of Research and Innovation (MCI) - EO-ROFORMON Project (http://www.eo-roformon. ro).

\section{References}

Aschoff T., Spiecker H., 2004. Algorithms for the automatic detection of trees in laser scanner data. The International Archives of Photogrammetry, Remote Sensing and Spatial Information Sciences, Freiburg, Deutschland, Vol. XXXVI, Part 8/ W2, pp. 66- 70.

Asner G.P, Mascaro J., 2014. Mapping tropical forest carbon: Calibrating plot estimates to a simple LiDAR metric. Remote Sensing of Environment 140: 614-624. DOI: 10.1016/j.rse.2013.09.023

Bauwens S., Bartholomeus H., Calders K., Lejeune P., 2016. Forest Inventory with Terrestrial LiDAR: A Comparison of Static and Hand-Held Mobile Laser Scanning. Forests 7(6): 1-17. DOI: 10.3390/f7060127

Bernasconi L., Chirici G., Marchetti, M., 2017. Biomass estimation of xerophytic forests using visible aerial imagery: Contrasting single-tree and area-based approaches. Remote Sensing 9(4): 1-12. DOI: 10.3390/ rs9040334

Blair J.B., Rabine D.L., Hofton M.A., 1999. The Laser Vegetation Imaging Sensor: a medium-altitude, digitisation-only, airborne laser altimeter for mapping vegetation and topography. ISPRS Journal of Photogrammetry and Remote Sensing 54: 115-122. DOI: 10.1016/ S0924-2716(99)00002-7

Boehm H.D., Liesenberg V., Limin S.H., 2013. Multi-temporal airborne LIDAR-survey and field measurements of tropical peat swamp forest to monitor changes. IEEE Journal of Selected Topics in Applied Earth Observations and Remote Sensing 6: 1524-1530. DOI: 10.1109/ JSTARS.2013.2258895

Brolly G., Kiraly G., 2009. Algorithms for stem mapping by means of terrestrial laser scanning. Acta Silvatica et Lignaria Hungarica 5: 119-130.

Brovkina O., Cienciala E., Surový P., Janata P., 2018. Unmanned Aerial Vehicles (UAV) for assessment of qualitative classification of Norway Spruce in temperate forest stands. Geo-Spatial Information Science 21(1): 12-20. DOI: 10.1080/10095020.2017.1416994

Brovkina O., Novotny J., Cienciala E., Zemek F., Russ R., 2017. Mapping forest aboveground biomass using airborne hyperspectral and LiDAR data in the mountainous conditions of Central Europe. Ecological Engineering, 100: 219-230. DOI: 10.1016/j.ecoleng.2016.12.004

Cabo C., Ordó-ez C., López-Sánchez C.A., Armesto J., 2018. Automatic dendrometry: Tree detection, tree height and diameter estimation using terrestrial laser scanning. International Journal of Applied Earth Observation and Geoinformation 69: 164-174. DOI: 10.1016/j.jag.2018.01.011

Fleck S., Mölder I., Jacob M., Gebauer T., Jungkunst H.F., Leuschner C., 2011. Comparison of conventional eightpoint crown projections with LIDAR-based virtual crown projections in a temperate old-growth forest. Annals of Forest Science 68: 1173-1185. DOI: 10.1007/ s13595-011-0067-1

Grudnicki F., 2004. Coeficientul de zvelteţe şi stabilitatea individuală a arborilor de molid [Standerness index and the individual stability of Norway spruce trees]. Bucovina Forestieră 12(1-2): 75-87.

Huang H., Li Z., Gong P., Cheng X., Clinton N., Cao C., Ni W., Wang L., 2011. Automated methods for measuring $\mathrm{DBH}$ and tree heights with a commercial scanning lidar. Photogrammetric engineering and remote sensing 77: 219-227. DOI: 10.14358/PERS.77.3.219

Keenan R.J., Reams G.A., Achard F., de Freitas J.V., Grainger A., Lindquist E., 2015. Dynamics of global forest area: results from the FAO global forest resources assessment 2015. Forest Ecology and Management 352: 9-20. DOI: 10.1016/j.foreco.2015.06.014

Liang X., Hyyppä J., 2013. Automatic stem mapping by merging several terrestrial laser scans at the feature and decision levels. Sensors 13: 1614-1634. DOI: 10.3390/ s130201614

Liang X., Kankare V., Hyyppä J., Wang Y., Kukko A., Haggrén H., Yu X., Kaartinen H., Jaakkola A., Guan F., 
Holopainen M., Vastaranta, M., 2016. Terrestrial laser scanning in forest inventories. ISPRS Journal of Photogrammetry and Remote Sensing 115: 63-77. DOI: 10.1016/j.isprsjprs.2016.01.006

Lovell J.L., Jupp D.L.B., Newnham G.J., Culvenor D.S., 2011. Measuring tree stem diameters using intensity profiles from ground-based scanning lidar from a fixed viewpoint. ISPRS Journal of Photogrammetry and Remote Sensing 66: 46-55. DOI: 10.1016/j.isprsjprs.2010.08.006

MacDicken K.G., 2015. Global forest resources assessment 2015: What, why and how? Forest Ecology and Management 352: 3-8. DOI: 10.1016/j.foreco.2015.02.006

Maas H.G., Bienert A., Scheller S., Keane E., 2008. Automatic forest inventory parameter determination from terrestrial laser scanner data. International Journal of Remote Sensing 29:5: 1579-1593. DOI: 10.1080/01431160701736406

Newnham G., Armstrong J., Muir J., Goodwin N., Culvenor D., Pushel P., Nystrom M., Johansen K., Tindall D. 2011. Evaluation of terrestrial laser scanners for measuring vegetation structure. CSIRO Australia. Sustainable Agriculture Flagship, Manuscript ID: EP 124571.

Niska H., Skon J., Packalen P., Tokola T., Maltamo M., Kolehmainen M., 2010. Neural networks for the prediction of species-specific plot volumes using airborne laser scanning and aerial photographs. IEEE Transactions on Geoscience and Remote Sensing 48: 1076-1085. DOI: 10.1109/TGRS.2009.2029864

Olofsson K., Holmgren J., Olsson H., 2014. Tree stem and height measurements using terrestrial laser scanning and the RANSAC algorithm. Remote Sensing 6: 4323-4344. DOI: 10.3390/rs6054323

Othmani A., Piboule A., Krebs M., Stolz C., Lew Yan Voon L. 2011. Towards automated and operational forest inventories with t-lidar. 11th International Conference on LiDAR Applications for Assessing Forest Ecosystems (SilviLaser 2011), October 2011, Hobart, Australia.

Pueschel P., Newnham G., Rock G., Udelhoven T., Werner W., Hill J., 2013. The influence of scan mode and circle fitting on tree stem detection, stem diameter and volume extraction from terrestrial laser scans. ISPRS Journal of Photogrammetry and Remote Sensing 77: 44-56. DOI: 10.1016/j.isprsjprs.2012.12.001

Simonse M., Aschoff T., Spiecker H., Thies M., 2003. au- tomatic determination of forest inventory parameters using terrestrial laser scanning. In: Proceedings of the ScandLaser Scientific Workshop on Airborne Laser Scanning of Forests, pp. 251-257.

Stanley T., 2013. Assessment of the FARO 3D focus laser scanner for forest inventory. BSc thesis, Faculty of Health, Engineering and Sciences, University of Southern Queensland, Toowooba, QLD, Australia, 86 p.

Tockner A., Leisch F., Nothdurft A., 2017. Automatic mapping of forest stands based on three-dimensional point clouds derived from terrestrial laser-scanning. Forests 8(8): 1-19.

Trumbore S., Brando P., Hartmann H., 2015. Forest health and global change. Science 349 (6250): 814-818. DOI: 10.1126/science.aac6759

Tubiello F.N., Salvatore M., Ferrara A.F., House J., Federici S., Rossi S., Prosperi P., 2015. The contribution of agriculture, forestry and other land use activities to global warming, 1990-2012. Global Change Biology 21(7): 2655-2660. DOI: 10.1111/gcb.12865

Vopěnka P, Černý M (2006). GIS aided Statistical Forest Inventory in Transcarpathia, Ukraine. ArcNews 27(4).

Wang P., Bu G., Li R., Zhao R., 2017. Automated lowcost terrestrial laser scanner for measuring diameters at breast height and heights of forest trees. arXiv: 1702.02235 .

Watt P.J., Donoghue D.N.M., 2005. Measuring forest structure with terrestrial laser scanning. International Journal of Remote Sensing, 26(7): 1437-1446. DOI: 10.1080/01431160512331337961

Weiß J., 2009. Application and statistical analysis of terrestrial laser scanning and forest growth simulations to determine selected characteristics of douglas-fir stands. Folia Forestalia Polonica 51(2): 123-137.

Wezyk P., Koziol K., Glista M., Pierzchalski M., 2007. Terrestrial laser scanning versus traditional forest inventory: First results from the Polish forests. In: Proc. Laser scanning 2007 and Silvilaser 2007. ISPRS Commission III Workshop, Vol. 36, Part 3, Espoo, Finland, Sept. 12-14, 2007, pp. 424-429. Web: http://www. isprs.org/proceedings/XXXVI/3-W52/final_papers/ Wezyk_2007.pdf. Accessed: 10.2018.

Zemánek T., Cibulka M., Pelikán P., Skoupil J., 2017. The use of terrestrial laser scanning for determining the driver's field of vision. Sensors 17(9): 2098. DOI: $10.3390 / \mathrm{s} 17092098$ 